\title{
Antineoplastic effect of a novel nanosized curcumin on cutaneous $\mathbf{T}$ cell lymphoma
}

\author{
ANTONIOS G.X. TROCHOPOULOS ${ }^{1}$, MAYA M. ZAHARIEVA ${ }^{2}$, MIRELA H. MARINOVA ${ }^{1}$, \\ KRASIMIRA YONCHEVA ${ }^{3}$, IVANKA PENCHEVA-EL TIBI ${ }^{4}$, MARTIN R. BERGER $^{5}$ and SPIRO M. KONSTANTINOV ${ }^{1}$ \\ ${ }^{1}$ Department of Pharmacology, Pharmacotherapy and Toxicology, Faculty of Pharmacy, \\ Medical University of Sofia, 1000 Sofia; ${ }^{2}$ Department of Infectious Microbiology, Institute of Microbiology \\ 'Stephan Angeloff', Bulgarian Academy of Sciences, 1113 Sofia; Departments of ${ }^{3}$ Pharmaceutical Technology and \\ Biopharmaceutics, and ${ }^{4}$ Pharmaceutical Chemistry, Faculty of Pharmacy, Medical University of Sofia, 1000 Sofia, \\ Bulgaria; ${ }^{5}$ Unit of Toxicology and Chemotherapy, German Cancer Research Center, D-69120 Heidelberg, Germany
}

Received February 17, 2020; Accepted August 11, 2020

DOI: $10.3892 / \mathrm{ol} .2020 .12167$

\begin{abstract}
Cutaneous T cell lymphomas (CTCLs) are a group of heterogeneous, life-threatening, extra-nodal and lymphoproliferative T cell neoplasms. Since chronic inflammation serves a key role in CTCL progression, curcumin, a natural pigment with proven anti-inflammatory and antineoplastic properties, as well as minimal toxicity, may be used as a therapeutic agent. In the present study, two formulations of curcumin (standard ethanolic and a Pluronic ${ }^{\circledR} \mathrm{P}-123 / \mathrm{F}-127$ micellar solution) were compared regarding their cytotoxic efficacy and speed of internalization in three CTCL cell lines, namely HuT-78, HH and MJ. In addition, the modulating effect of curcumin on selected proteins involved in the proliferation and progression of the disease was determined. The results indicated the superiority of the Pluronic ${ }^{\circledR} \mathrm{P}-123 / \mathrm{F}-127$ micellar curcumin over the standard ethanol solution in terms of cellular internalization efficiency as determined by spectrophotometric analysis. Notably, the presence of commonly used media components, such as phenol red, may interfere when interpreting the cytotoxicity of curcumin, due to their overlapping absorbance peaks. Therefore, it was concluded that phenol red-free media are superior over media with phenol red in order to correctly measure the cytotoxic efficacy and cell penetration of curcumin. Depending on the cell line, the $\mathrm{IC}_{50}$ values of micellar curcumin varied from 29.76 to $1.24 \mu \mathrm{M}$, with $\mathrm{HH}$ cells demonstrating the highest sensitivity. This cell line had the lowest expression levels of
\end{abstract}

Correspondence to: Dr Antonios G.X. Trochopoulos, Department of Pharmacology, Pharmacotherapy and Toxicology, Faculty of Pharmacy, Medical University of Sofia, 2 Dunav Street, 1000 Sofia, Bulgaria

E-mail: trochopoulos.antonios@outlook.com

Key words: cutaneous T cell lymphoma, NF-кB inhibition, Wilms' tumor-1, anaplastic lymphoma kinase, JAK, STAT, phospholipase C $\gamma$ signal transduction, curcumin, micelles, phenol red interactions the Wilms' tumor-1 transcription factor. Performing western blot analyses of treated and untreated CTCL cells, selective signal transduction changes were recorded for the first time, thus making curcumin nano-formulation an attractive and prospective option with therapeutic relevance for CTCL as a rare orphan disease.

\section{Introduction}

Cutaneous T-cell lymphomas (CTCLs) are a group of heterogeneous lymphoproliferative diseases (1), with malignant cells possessing skin-homing properties (2). The World Health Organization-European Organization for Research and Treatment of Cancer classification for cutaneous lymphomas, published by Willemze et al (3), segregates CTCLs into sixteen forms (including subtypes). However, the present study only examined the most common manifestations of the disease, namely mycosis fungoides (MF) and Sézary syndrome (SS). $\mathrm{MF}$ is a rare indolent type of skin tumor following a relatively benign course, characterized by the accumulation of peripheral $\mathrm{CD}^{+} / \mathrm{CD} 45 \mathrm{R} 0^{+}$helper $\mathrm{T}$ cells in the skin (4). These $\mathrm{T}$ cells are present on parts of the skin as patches similar to those typical for eczema, atopic dermatitis and especially psoriasis (5), thus making its early diagnosis challenging, and the disease may obscurely progress to a cutaneous nodular or even tumor stage (6). When the latter is accompanied by systemic involvement, MF transforms to its 'leukemic form', SS (although MF is not always a prerequisite for SS) (1,7-11).

In order to evaluate the stage of the disease, a number of examinations must be performed according to the algorithm developed by the International Society for Cutaneous Lymphomas, such as complete physical examination, skin and lymph node biopsies and blood and radiological tests (12). Depending on the diagnosis, treatment may vary from skin-directed therapies using topical corticosteroids, bexarotene, Psoralen-UVA, UVB, topical chemotherapy and photodynamic therapy, to a systemic approach using intravenous chemotherapy, interferon- $\alpha$ and histone deacetylase inhibitors, with stem cell transplantation as an option for very advanced cases $(12,13)$. However, it is of paramount importance 
to consider that these guidelines are based on a limited database with very few randomized trials performed This is due to the frequency of CTCL occurrence, as primary cutaneous lymphomas make $\approx 5 \%$ of non-Hodgkin's lymphomas $(14,15)$, and CTCLs in turn make $\approx 65 \%$ of primary cutaneous lymphomas (16). Therefore, it is clear that the incidence of CTCLs is scarce, which is why both the USA Food and Drug Administration and the European Medicines Agency classify CTCL as a rare disease (17). In addition, CTCL is registered under the codes ORPHA:2584 for MF and ORPHA:3162 for SS in the Orphanet database (18). Thus, it is unlikely for an orphan disease to be the subject of numerous clinical trials. Further insight into the pathogenesis and the specific characteristics of the disease is required in order to develop novel therapeutic modalities.

An important feature of patients with a progressive stage of CTCL, especially those with erythrodermic cutaneous T-cell lymphoma (a group to which SS belongs as a leukemic variant of (TCL) is that they often have decreased levels of normal blood $\mathrm{T}$ cells, which is also seen in patients with advanced acquired immunodeficiency syndrome (AIDS) (19,20). This is because the malignant $\mathrm{T}$ cell clone expands at the expense of normal $\mathrm{T}$ cells, creating a deficiency in the number of the latter $(21,22)$. Since the immune system is compromised in these patients, one should proceed carefully in the selection of novel therapeutic agents, opting for those that are well tolerated, in order to avoid immune collapse, given the fact that current therapies exhibit a marked immunotoxicity (23-29). This problem becomes more obvious considering that patients with CTCL are more susceptible to infections due to the impaired skin barrier caused by tumors and/or lesions (30).

Considering the aforementioned points, curcumin, a natural compound derived from the rhizome of the plant Curcuma longa L., with proven anti-inflammatory, antioxidant, antimicrobial and antineoplastic properties (31), and with minimal toxicity (32), remains a favorable candidate for the treatment of CTCL. Numerous studies regarding the cytotoxic effect of curcumin on CTCL cell lines have already been published (33-35). Additionally, this polyphenolic compound possesses antimicrobial activity (36-38) as it inhibits the growth of highly pathogenic Staphylococcus aureus strains, which are the cause of the most common infections affecting patients with CTCL $(39,40)$ and are probably a liable factor in the malignant progression of this disease (41). Curcumin is absorbed poorly after oral administration (42). This can be explained since this natural polyphenolic compound is practically insoluble in water, is photodegradable and has a very fast metabolism and a short half-life (43). Overall, it is clear that curcumin administered orally results in very low plasma concentrations $(44,45)$. With low bioavailability being a major drawback for developing curcumin as a therapeutic agent, a number of studies are trying to improve the pharmacokinetics of natural substances by using various nano-formulations as transport vehicles (46-51).

In the present study, curcumin was incorporated in micelles based on one or two copolymers: Pluronic ${ }^{\circledR} \mathrm{P}-123$ or a mixture of Pluronic ${ }^{\circledR} \mathrm{P}-123$ and Pluronic ${ }^{\circledR} \mathrm{F}-127$ in a $1: 1$ ratio. The present study aimed to compare these micellar formulations to the commonly used ethanol $(\mathrm{EtOH})$ solution of curcumin, by analyzing the antineoplastic efficacy and internalization rate. Throughout the present report, the aforementioned solutions will be abbreviated as CRM (EtOH), CRM (P123) and CRM (P123/F127). In order to elucidate the molecular mode of action, the effect of curcumin on key signal transduction proteins associated with tissue inflammation, cell proliferation and survival was analyzed.

\section{Materials and methods}

Chemicals and reagents. Curcumin (molecular weight, $489,722 \mathrm{~g} / \mathrm{mol}$; cat. no. C1386), absolute ethanol (cat. no. 46139) and the MTT dye (cat. no. M2128) were purchased from Sigma-Aldrich; Merck KGaA. Pluronic ${ }^{\circledR} \mathrm{P}-123$ $\left(\mathrm{PEO}_{20} \mathrm{PPO}_{70} \mathrm{PEO}_{20}\right)$ and Pluronic ${ }^{\circledR} \mathrm{F}-127\left(\mathrm{PEO}_{101} \mathrm{PPO}_{56} \mathrm{PEO}_{101}\right)$ were provided by BASF SE.

Cell lines and culture conditions. All three human cell lines, namely HuT-78 (for SS; cat. no. TIB-161 ${ }^{\mathrm{TM}}$ ), MJ (for MF; cat. no. CRL-8294 ${ }^{\mathrm{TM}}$ ) and HH (cat. no. CRL-2105 ${ }^{\mathrm{TM}}$ ), are derived from CTCL and were purchased from the American Type Culture Collection. The cell lines were tested for mycoplasma infection using an EZdetect ${ }^{\mathrm{TM}}$ PCR kit (cat. no. CCK022-25R) for mycoplasma detection, obtained from HiMedia Laboratories Pvt. Ltd.. Two types of the recommended culture media were used for each cell line, with the only difference being the presence or absence of phenol red and were purchased from Gibco; Thermo Fisher Scientific, Inc. For the HuT-78 and MJ cell lines, the culture media used were Iscove's Modified Dulbecco's Media (IMDM) with (cat. no. 1852716) or without phenol red (cat. no. 1929922), both supplemented with $20 \%$ FBS (cat. no. P160706; PAN-Biotech GmbH) and 5\% L-glutamine (cat. no. 1978288; Gibco; Thermo Fisher Scientific, Inc.). For the $\mathrm{HH}$ cell line, the culture media used were RPMI-1640 with (cat. no. 1924313) or without phenol red (cat. no. 1945343) supplemented with $10 \%$ FBS and $5 \%$ L-glutamine. The culture conditions were $37^{\circ} \mathrm{C}, 5 \% \mathrm{CO}_{2}$, with the incubation period after treatment being $24 \mathrm{~h}$.

Preparation and characterization of micelles. Curcumin was incorporated into mixed micelles based on Pluronic ${ }^{\circledR} \mathrm{P}-123$ or a mixture of Pluronic ${ }^{\circledR} \mathrm{P}-123$ and Pluronic ${ }^{\circledR} \mathrm{F}-127$ triblock copolymers as previously described (38). Briefly, curcumin and both copolymers were simultaneously dissolved in methanol. Subsequently, the methanol was completely evaporated and the film was dispersed in purified water to give aqueous micellar dispersion. The freshly prepared dispersion was filtered $(0.22 \mu \mathrm{m})$ and the fractions collected after rinsing the filter with ethanol were spectrophotometrically evaluated at $428 \mathrm{~nm}$ (Thermo Fisher Scientific, Inc.) for the presence of non-encapsulated curcumin. The size and zeta-potential of the curcumin-loaded mixed micelles CRM (P123/F127) were examined using photon correlation spectroscopy and electrophoretic laser Doppler velocimetry (Zetamaster analyzer; Malvern Instruments, Ltd.).

Optimization of the MTT-dye reduction assay. Phenol red (phenolsulfonphthalein) is a substance used as a $\mathrm{pH}$ indicator in numerous cell culture media. Its color exhibits a gradual transition from yellow $\left(\lambda_{\max }=443 \mathrm{~nm}\right)$ to $\operatorname{red}\left(\lambda_{\max }=570 \mathrm{~nm}\right)$ over a $\mathrm{pH}$ range from 6.8 to 8.2 ; at $\mathrm{pH}>8.2$, phenol red turns 
bright pink (52). Curcumin and phenol red have absorption maxima of 428 and $436 \mathrm{~nm}$ respectively, and a spectrophotometric analysis was performed with both substances, in order to detect the presence of overlapping absorbance peaks that may lead to false interpretation of the cytotoxic results (Fig. 1). The spectrometer used for this analysis was a HP UV/VIS-spectrometer (Diode array detector; wavelength range, 190-820 nm; wavelength accuracy, $\pm 2 \mathrm{~nm}$ ) supplied by Agilent Technologies.

Optimized MTT assay for the evaluation of cell survival. The cell survival rate was measured using the MTT dye reduction assay as described by Mosmann (53), with slight protocol modifications as previously described (54). This method is based on the reduction of the yellow tetrazolium salt MTT to a violet MTT-formazan by the mitochondrial succinate dehydrogenase in viable cells (55). Briefly, cells from the three CTCL cell lines (HuT-78, HH and MJ) were seeded in 96-well plates with $100 \mu \mathrm{l} /$ well and a density of $0.35 \times 10^{6}$ cells $/ \mathrm{ml}$. After $24 \mathrm{~h}$ of incubation at $37^{\circ} \mathrm{C}$ with $5 \% \mathrm{CO}_{2}$, the cells were treated with different concentrations $(100,80,60,40,20,10,5,2.5$, 1.25 and $0.625 \mu \mathrm{M})$ of CRM (EtOH) and CRM (P123/F127) and placed back in the incubator. After 24, 48 and $72 \mathrm{~h}$, MTT solution $(5 \mathrm{mg} / \mathrm{ml}$ in PBS) was added. The cells were further incubated for $3 \mathrm{~h}$ and $30 \mathrm{~min}$ at $37^{\circ} \mathrm{C}$ with $5 \% \mathrm{CO}_{2}$. The formazan crystals formed by the cells from the metabolism of MTT were dissolved by adding $110 \mu \mathrm{l} /$ well 95\% 2-propanol and $5 \% \mathrm{HCl}$. Absorbance was measured using a photometer (Anthos 2001; Anthos Labtec Instruments $\mathrm{GmbH}$ ) at $540 \mathrm{~nm}$, using a reference filter of $690 \mathrm{~nm}$. For every concentration, $\geq 8$ wells were used. In a well containing $100 \mu \mathrm{l}$ of the respective culture media, $10 \mu \mathrm{l}$ of MTT and $110 \mu 1$ 95\% 2-propanol (96\%) and $5 \% \mathrm{HCl}(37 \%)$ was used as blank. The cell survival rate was calculated as a percentage of the untreated control, using GraphPad Prism software (version 6.01 for Windows, GraphPad Software, Inc.). $\mathrm{IC}_{25}, \mathrm{IC}_{50}$ and $\mathrm{IC}_{75}$ values of curcumin were calculated from the concentration-response curves using the non-linear regression mathematical equation $\mathrm{Y}=100 /\left(1+10^{\wedge}\left((\log \mathrm{IC} 50-\mathrm{X})^{*}\right.\right.$ HillSlope $\left.\left.)\right)\right)$ available in the software under section 'Dose-response inhibition' as ' $\log$ (inhibitor) vs. normalized response, Variable slope'. Least square fit was used as fitting model. For presentation of the data points 'mean \pm SD' was chosen. The Pearson correlation coefficient was also calculated for the data. The values presented on Fig. 2 are the values of the square of $\mathrm{r}$ computed from the sum of the squares of the distances of the points from the best-fit curve determined by nonlinear regression.

Spectrophotometric measurement for the evaluation of curcumin internalization. To compare the internalization rate of the two different curcumin formulations into HuT-78, $\mathrm{HH}$ and MJ cells, a spectrophotometric analysis was performed. Briefly, cells were treated with the two different curcumin formulations and after 1-3 and $24 \mathrm{~h}$, the culture medium was collected after separation from the cells by centrifugation $(277 \mathrm{x} \mathrm{g}$ at room temperature for $5 \mathrm{~min})$. Subsequently, $4.5 \mathrm{ml}$ solvent mixture of acetonitrile: Methanol (1:1 v/v) was added to the tubes containing the culture media. The samples were sonicated $(35 \mathrm{kHz})$ at $20^{\circ} \mathrm{C}$ for 5 min and centrifuged to separate the precipitate $(277 \mathrm{x} \mathrm{g}$ at room temperature for
5 min). The supernatant mixtures were filtered and subjected to spectrophotometric determination against blank solution that was similarly prepared. This method was performed to determine the amount of curcumin in the cell culture media. The more curcumin was contained in the culture media, the less was internalized into the cells during the incubation. The method's analysis options used in this experiment were as follows: Multicomponent analysis, Beer's Law Calibration Curve type, Least Squares fit algorithm, derivative order of 0 , polynomial degree of 0 , one smoothing point, data interval of $2,428 \mathrm{~nm}$ analytical wavelength and $25^{\circ} \mathrm{C}$ temperature. The reagents used included: Curcumin reference substance (RS), acetonitrile and methanol, all supplied by Sigma-Aldrich; Merck KGaA.

Western blotting. In order to observe protein expression changes induced by curcumin, immunoblot analyses were performed. Cells from the three CTCL cell lines were seeded at a density of $2 \times 10^{6}$ in $25 \mathrm{~cm}^{2}$ culture flasks followed by curcumin treatment with various concentrations [respective $\mathrm{IC}_{25}, \mathrm{IC}_{50}$ and $\mathrm{IC}_{75}$ values for CRM (EtOH) and 2.5, 5, 10 and $20 \mu \mathrm{M}$ CRM (P123/F127) on HuT-78 cells]. The incubation period was $24 \mathrm{~h}\left(37^{\circ} \mathrm{C}, 5 \% \mathrm{CO}_{2}\right)$. The content of the flasks was harvested and lysed with RIPA buffer $(150 \mathrm{mM}$ $\mathrm{NaCl}, 1 \%$ Triton $\mathrm{X}-100,0.5 \%$ Na deoxycholate, $0.1 \%$ SDS and $50 \mathrm{mM}$ Tris; Thermo Fisher Scientific, Inc.), supplemented with complete protease inhibitor cocktail tablets and $\mathrm{Na}_{2} \mathrm{VO}_{3}(10 \mu \mathrm{M})$. The Bradford assay (56) was performed to estimate the protein concentration of each sample using Carl Roth ${ }^{\circledR}$ Roti $^{\circledR}$-Nanoquant (cat. no. K880.2) and BSA (cat. no. 8076.1) as a calibrating protein, both supplied by Carl Roth Gmbh \& Co. Kg. The lysates were mixed with the required amount of NuPAGE ${ }^{\circledR}$ LDS Sample Buffer (4X; cat. no. 2083421; Invitrogen; Thermo Fisher Scientific, Inc.). After $5 \mathrm{~min}$ at $99^{\circ} \mathrm{C}$, the samples $(20 \mu \mathrm{l}$ each) were separated on FastGene ${ }^{\circledR}$ PAGE 4-20\% gels (cat. no. G34121812; Nippon Genetics Europe GmbH) via SDS-PAGE. The proteins were transferred onto PVDF membranes (cat. no. 88520; Thermo Fisher Scientific, Inc.) blocked for $1 \mathrm{~h}$ at room temperature (1X TBS supplemented with 5\% skim milk powder and $0.1 \%$ Tween-20) and blotted for the target proteins using the following primary monoclonal antibodies (mAbs): Bad (Rabbit mAb; cat. no. 9239; dilution 1:1,000), Bax (Rabbit mAb; cat. no. 5023; dilution 1:1,000), Bcl-2 (Rabbit mAb; cat. no. 3498; dilution 1:1,000) ALK (Rabbit mAb; cat. no. 3633; 1:2,000), Phospho-Janus kinase (p-Jak)3 (Tyr980/981; Rabbit mAb; cat. no. 5031; dilution 1:1,000), Phospho-Janus kinase (p-Jak)2 (Tyr1007; Rabbit mAb; cat. no. 3771; dilution 1:1,000), mTOR (Rabbit mAb; cat. no. 2983; dilution 1:1,000), Phospho-mTOR (Rabbit mAb; cat. no. 5536; dilution 1:1,000), p-Stat3 (Tyr705; XP ${ }^{\circledR}$ Rabbit mAb; cat. no. 9145; dilution 1:1,000), p-Stat5 (Tyr694; $\mathrm{XP}^{\circledR}$ Rabbit mAb; 4322; 1:1,000), p-phospholipase (PLC $\gamma 1$ (Tyr783; Rabbit mAb; cat. no. 14008; dilution 1:1,000), Raptor (Rabbit mAb; cat. no. 2280; dilution 1:1,000), Rictor (Rabbit mAb; cat. no. 2114; dilution 1:1,000), p-glycogen synthase kinase (GSK)-3 $\beta$ (Ser9; cat. no. 9336; dilution 1:1,000), p21 Waf1/Cip1 (Rabbit mAb; cat. no. 2947; dilution 1:1,000), p-NF-кB p65 (Ser536; Rabbit mAb; cat. no. 3033; dilution 1:1,000), all from Cell Signaling Technology, Inc., and Wilms' 


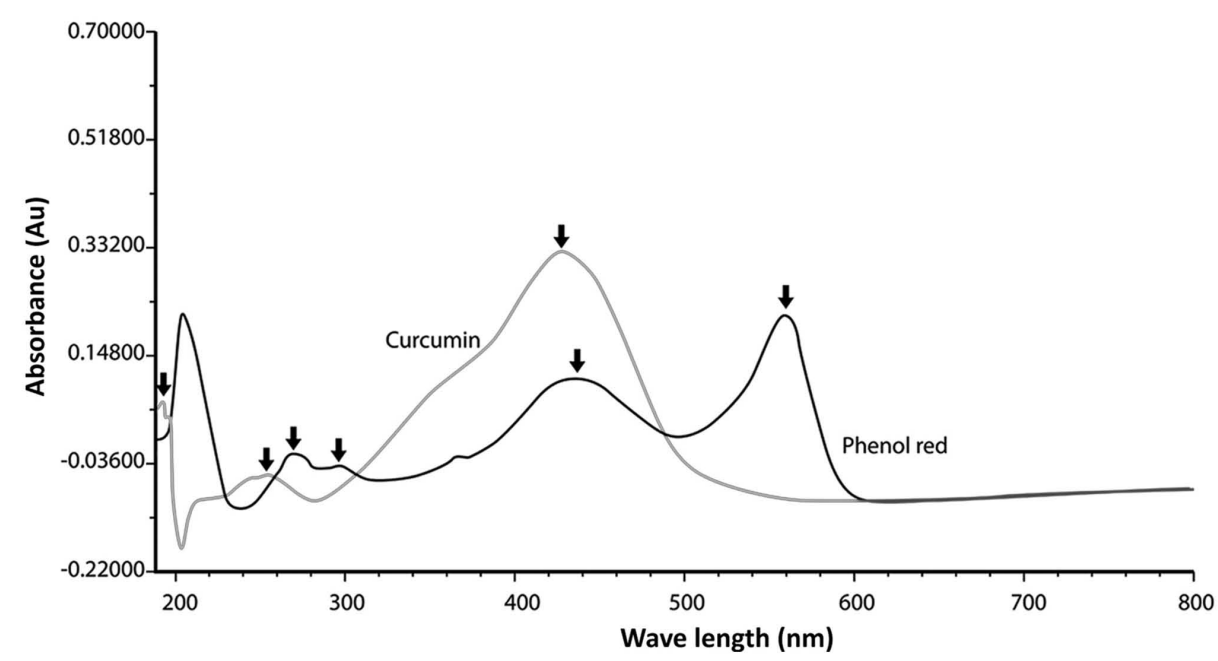

Figure 1. Overlapping spectra analysis of curcumin and phenol red. The arrows denote the overlapping of the absorbance peaks of the two substances, especially visible between 400 and $500 \mathrm{~nm}$

tumor 1 (WT-1) (Mouse mAb;cat. no. sc-7385; dilution 1:500) supplied by Santa Cruz Biotechnology, Inc. HRP-conjugated secondary anti-rabbit (cat. no. 7074) and anti-mouse (cat. no. 7076) IgG antibodies (Cell Signaling Technology, Inc.; both at 1:2,000 dilution) were applied and a Pierce ${ }^{\mathrm{TM}}$ ECL Western Blotting Substrate (cat. no. 32209) supplied by Thermo Fisher Scientific, Inc. was used to visualize the immunoblots. Normalization of protein levels was achieved using the expression levels of $\beta$-actin (cat. no. sc-47778; dilution 1:1,000) supplied by Santa Cruz Biotechnology, Inc.and densitometry was performed using ImageJ software (1.52p; Java 1.8.0_112; 64-bit; National Institutes of Health) (57).

ELISA measurement of $N F-\kappa B$ transcription factor activation. Comparison of the expression levels of total and phosphorylated human NF-кB p65 was performed in CTCL cells treated either with micellar curcumin, CRM (P123/F127), or with the standard ethanolic solution of curcumin, CRM (EtOH) using two concentrations for each formulation, 2.5 and $5 \mu \mathrm{M}$. The cells were incubated at $37^{\circ} \mathrm{C}$ supplied with $5 \% \mathrm{CO}_{2}$ for $24 \mathrm{~h}$. The procedure was performed using a NFkB p65 (Total/Phospho) ELISA kit (cat. no. ADI-EKS-446) supplied by Enzo Life Sciences, Inc., according to the manufacturer's protocol. The obtained data was analyzed using the protein array analyzer written for ImageJ, designed by Gilles Carpentier, 2008 (58).

Statistical analysis. All experiments were performed in triplicate. The Student's t-test was used to compare the control and the treated groups in Fig. 3. Multiple comparisons were performed using one-way ANOVA followed by the post hoc Tukey's test (Fig. 4). P $<0.05$ was considered to indicate a statistically significant difference. The data are presented as the mean \pm standard deviation. All experiments were performed using GraphPad Prism software (version 6.01 for Windows; GraphPad Software, Inc.).

\section{Results}

Optimization of the MTT assay for curcumin solutions. Fig. 1 shows that phenol red, a common $\mathrm{pH}$-indicator present in a wide range of culture media, may interfere with the results obtained when measuring the cytotoxic efficacy of curcumin on suspension cell cultures using the MTT dye reduction assay. This is due to the relatively contiguous absorbance peaks of both substances (428 $\mathrm{nm}$ for curcumin and $436 \mathrm{~nm}$ for phenol red). Considering the prominence of curcumin in scientific studies, the present result may be of great importance in the optimization of colorimetric assays that investigate this natural substance.

MTT tests with and without phenol red. As expected, the results of the experiments on cytotoxicity exhibited marked differences in the $\mathrm{IC}_{50}$ values in the presence or absence of phenol red (Fig. 2). These differences were visible throughout all studied time intervals $(24,48$ and $72 \mathrm{~h}$ ) and did not depend on the curcumin formulation used, CRM (EtOH) or CRM (P123). Since the empty Pluronic ${ }^{\circledR} \mathrm{P}-123$ poloxamers exhibited a high toxicity (Fig. S1), the present study aimed to identify an improved nano-formulation for subsequent experiments. The objective of the current study was to compare solely the cytotoxic properties of curcumin between different formulations and not the cytotoxic effects of the carrier itself.

Characterization of the micellar solution consisting of Pluronic ${ }^{\circledR}$ P-123 and Pluronic ${ }^{\circledR}$ F-127 (1:1 v/v). The preparation and loading of curcumin into the micellar solution consisting of Pluronic ${ }^{\circledR}$ P-123 and Pluronic ${ }^{\circledR}$ F-127 (1:1 v/v) was performed using the film hydration method, which has been reported as the most appropriate procedure in a previous study (38). The resulting micelles had a slightly negative zeta-potential $(\sim 7 \mathrm{mV})$ and a small particle diameter $(\sim 55 \mathrm{~nm})$, which was considered a prerequisite for their stability. In addition, the small diameter was considered advantageous for the intracellular transport of curcumin-loaded micelles. The novel nano-formulation did not exhibit considerable cytotoxic activity, resulting in a more appropriate nano-formulation for the present study of the specific curcumin cytotoxicity (Fig. S2).

Comparison of the antiproliferative efficacy of curcumin in ethanol and micellar solutions. The comparison between the antiproliferative efficacies of the novel micellar solution of 
Table I. Cytotoxic comparison between the two formulations of curcumin on the three cell lines after 24, 48 and $72 \mathrm{~h}$ of treatment.

\begin{tabular}{llccc}
\hline & & \multicolumn{3}{c}{$\mathrm{IC}_{50}(95 \% \mathrm{CI}), \mu \mathrm{M}$} \\
\cline { 3 - 5 } Cell line & Curcumin formulation & $24 \mathrm{~h}$ & $48 \mathrm{~h}$ & $72 \mathrm{~h}$ \\
\hline \multirow{2}{*}{ HuT-78 } & CRM $(\mathrm{EtOH})$ & $43.18(40.07-43.18)$ & $36.90(34.04-40.00)$ & $27.33(22.13-33.74)$ \\
& CRM (P123/F127) & $29.76(23.65-38.02)$ & $6.58(5.80-7.40)$ & $3.91(3.65-4.18)$ \\
HH & CRM (EtOH) & $23.61(21.45-25.99)$ & $19.40(18.60-20.24)$ & $14.74(12.94-17.17)$ \\
MJ & CRM (P123/F127) & $4.13(1.81-8.02)$ & $5.07(3.763-6.25)$ & $1.24(0.68-2.22)$ \\
& CRM (EtOH) & $30.45(28.28-32.79)$ & $33.28(29.00-38.19)$ & $16.09(15.09-17.17)$ \\
& CRM (P123/F127) & $26.16(15.35-46.81)$ & $4.16(2.73-5.76)$ & $2.93(2.74-3.14)$ \\
\hline
\end{tabular}

CRM (EtOH), ethanolic solution of curcumin; CRM (P123/F127), curcumin-loaded micelles consisting of Pluronic ${ }^{\circledR} \mathrm{P}-123$ and Pluronic ${ }^{\circledR} \mathrm{F}-127$ $(1: 1 \mathrm{v} / \mathrm{v})$.
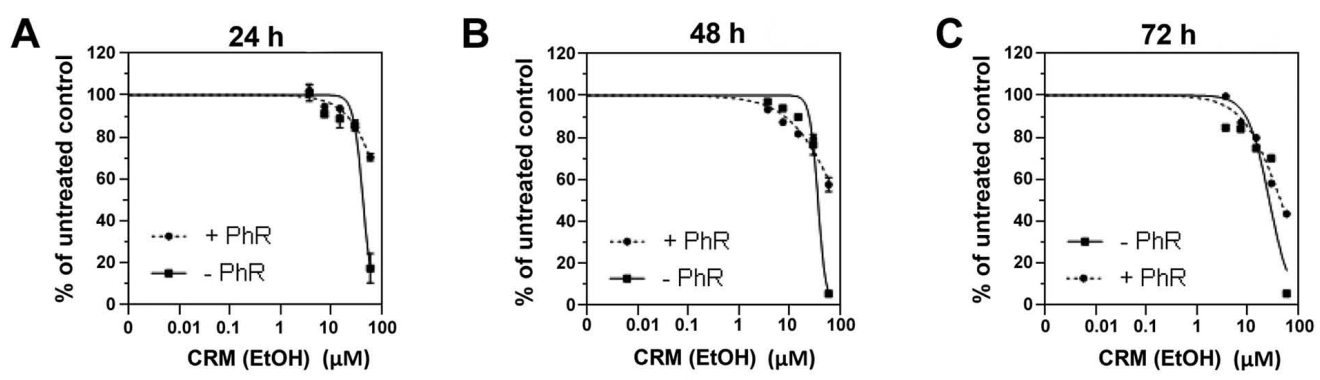

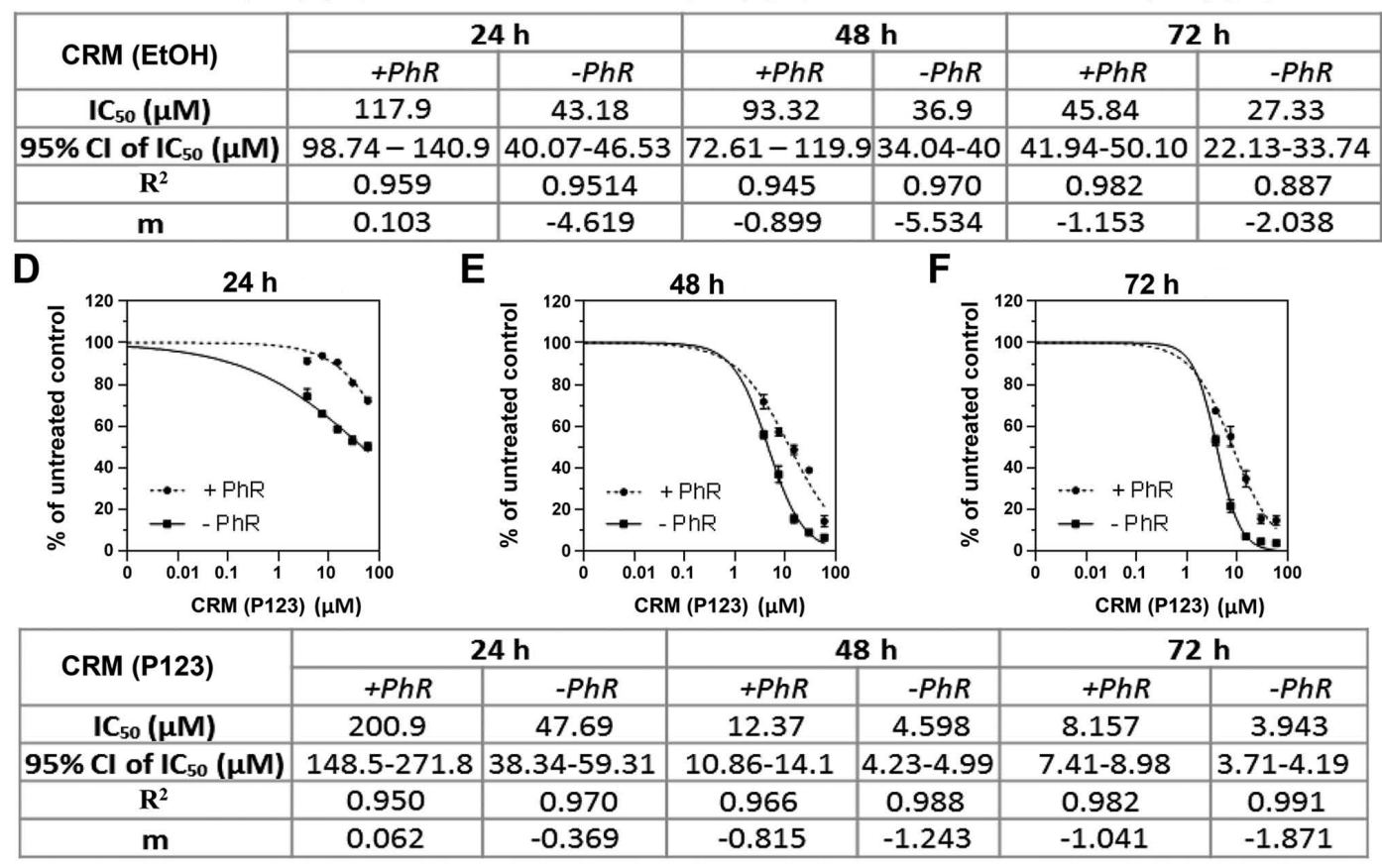

Figure 2. MTT assays revealing the negative role of PhR in the calculation of the $\mathrm{IC}_{50}$ values. MTT assay with CRM (EtOH) after (A) 24 , (B) 48 and (C) $72 \mathrm{~h}$. MTT assay with CRM (P123) after (D) 24, (E) 48 and (F) 72 h. CRM (EtOH), ethanolic solution of curcumin; CRM (P123), curcumin-loaded Pluronic ${ }^{\circledR}$ P-123 micelles; R2-correlation coefficient; m-hillslope; PhR, phenol red.

curcumin and the standard ethanolic one was performed via MTT dye reduction assay (Table I). The results clearly demonstrated that CRM (P123/F127) exhibited a clear superiority over the cytotoxic efficacy of the CRM $(\mathrm{EtOH})$ in all cell lines. For instance, regarding the most resistant cell line, HuT-78, after $24 \mathrm{~h}$ of treatment the $\mathrm{IC}_{50}$ value of CRM (P123/F127) was $29.76 \mu \mathrm{M}$ compared with that of CRM (EtOH) which was significantly higher $(43.18 \mu \mathrm{M})$. A more profound difference was observed when comparing the $\mathrm{IC}_{50}$ values after $48 \mathrm{~h}$, $6.58 \mu \mathrm{M}$; CRM (P123/F127)/36.90 $\mu \mathrm{M}$; CRM (EtOH) and 72 h, $3.91 \mu \mathrm{M}$; CRM (P123/F127)/27.33 $\mu \mathrm{M}$; CRM (EtOH).

Comparison of the internalization rate of curcumin in ethanol and micellar solutions. In order to obtain information 

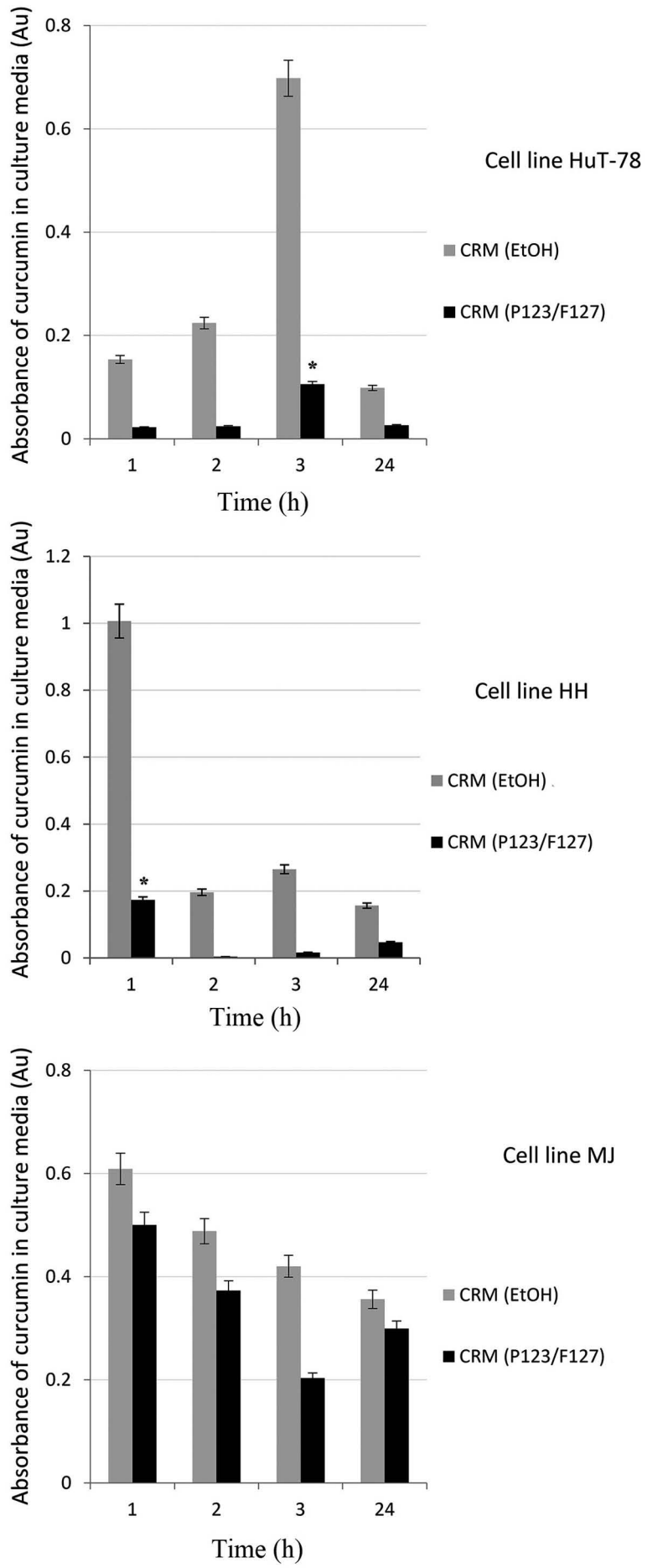

Figure 3. Spectrophotometric analysis of the absorbance of CRM contained in the culture media after $1-3$ and $24 \mathrm{~h}$ of treatment with $50 \mu \mathrm{M}$ CRM (EtOH) and CRM (P123/F127). ${ }^{*} \mathrm{P} \leq 0.05 . \mathrm{CRM}(\mathrm{EtOH})$, ethanolic solution of curcumin; CRM (P123/F127), curcumin-loaded micelles consisting of Pluronic ${ }^{\circledR} \mathrm{P}-123$ and Pluronic ${ }^{\circledR} \mathrm{F}-127(1: 1 \mathrm{v} / \mathrm{v})$. Data is presented as mean \pm SD.

regarding the speed of internalization of both curcumin formulations, spectrophotometry was performed using a $\mathrm{UV} / \mathrm{Vis}$-spectrometer. The results from the spectrophotometric analysis of remaining curcumin amounts in the culture media from both formulations after different time intervals are shown in Fig. 3. CRM (P123/F127) penetrated the cells faster, hence the lower concentration of curcumin in the supernatant media, compared with CRM (EtOH). According to the

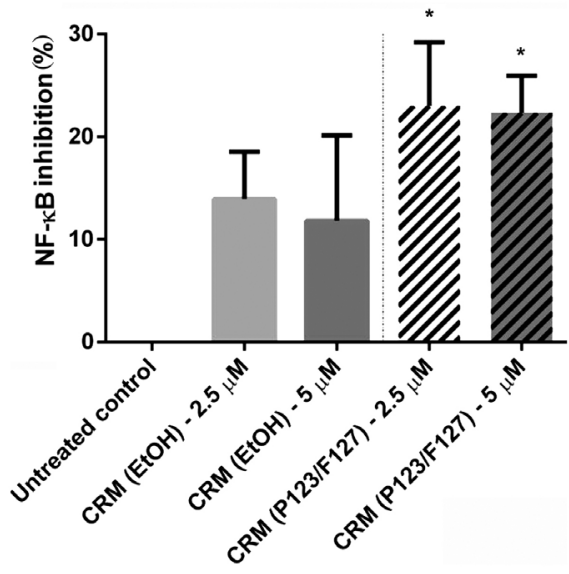

Figure 4. NF- $\mathrm{B}$ inhibition comparison between the two curcumin formulations in HuT-78 cells. CRM (P123/F127) inhibited NF- $\kappa$ B more efficiently than $\mathrm{CRM}(\mathrm{EtOH})$ at both concentrations after $24 \mathrm{~h}$ of treatment. ${ }^{*} \mathrm{P} \leq 0.05$ vs. the respective concentrations of CRM (EtOH). CRM (EtOH), ethanolic solution of curcumin; CRM (P123/F127), curcumin-loaded micelles consisting of Pluronic ${ }^{\circledR} \mathrm{P}-123$ and Pluronic ${ }^{\circledR} \mathrm{F}-127$ (1:1 v/v). Data are presented as mean $\pm \mathrm{SD}$. The asterisks denote significant difference from the untreated control (unpaired Student's t-test, $\mathrm{P}<0.05$ ).

Lambert-Beer law, the absorbance of a light-absorbing material (such as curcumin) must be proportional to its concentration in a solution (59). The higher the concentration of curcumin in the culture media, the lower its concentration in the CTCL cells. Therefore, CRM (P123/F127) appeared to have a faster internalization rate than CRM $(\mathrm{EtOH})$.

$N F-\kappa B$ inhibition between curcumin in ethanol and micellar solutions. NF- $\kappa \mathrm{B}$ is a transcription factor involved in the regulation of immune and inflammatory responses $(60,61)$. Similarly to numerous neoplasms $(62,63)$, CTCL is also known to have constitutive NF- $\kappa \mathrm{B}$ activation (64-66), which functions by inhibiting cell death through the transcriptional induction of genes encoding anti-apoptotic proteins, thus making it a desirable therapeutic target. In order to detect changes in the activation levels of NF- $\kappa$ B induced by curcumin, a NF- $\kappa$ B p65 (Total/Phospho) ELISA kit was used in the present study. Chemiluminescent signals from samples, after normalization to the untreated control (set to $0 \%$ ), revealed that $\mathrm{NF}-\kappa \mathrm{B}$ inhibition in HuT-78 cells was significantly higher using both concentrations of CRM (P123/F127) compared with using the respective concentrations of CRM (EtOH) (Fig. 4). Notably, the amount of curcumin released from the micelles after $24 \mathrm{~h}$ of incubation equals up to $38 \%$ of the initial concentration (38), a fact that makes the micellar formulation even more potent.

Inhibition of $p-N F-\kappa B$ p65, ALK, p-Jak2 and p-Jak3 by curcumin. In accordance with the aforementioned results, CRM (EtOH) downregulated the phosphorylated form of $\mathrm{NF}-\kappa \mathrm{B}$ p65, as measured via western blotting in HuT-78 and $\mathrm{HH}$ cells (Fig. 5). p-NF- $\kappa \mathrm{B}$ p65 was also downregulated in MJ cells (data not shown). Additionally, ALK downregulation and dephosphorylation of p-Jak2 and p-Jak3 was observed in a concentration-dependent manner in HuT-78 and MJ cells (Fig. 5).

Immunoblot analysis to detect the presence of WT-1 using only control groups. WT-1 is a transcription factor that in humans 


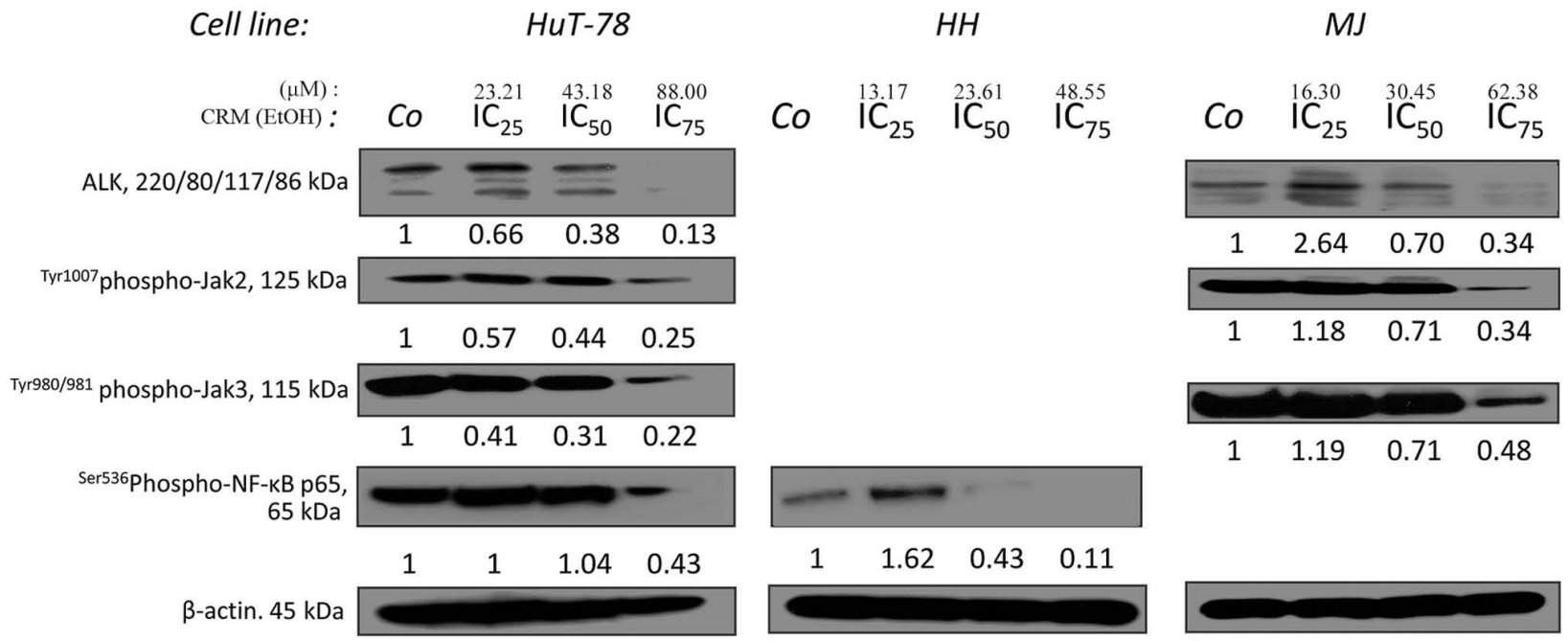

Figure 5. Effect of CRM (EtOH) on the expression levels of phospho-NF-кB p65, ALK, phospho-Jak2 and phospho-Jak3 after 24 h of treatment. The numbers under the protein bands indicate the fraction of the untreated control calculated via densitometric analysis. CRM (EtOH), ethanolic solution of curcumin; Co., untreated control; ALK, anaplastic lymphoma kinase; Jak, Janus kinase.

is encoded by the WT-1 gene on chromosome 11p (67-69). It is commonly detected in malignant non-differentiated cells and its upregulation is a poor prognostic factor as it negatively affects the clinical outcome in a variety of tumors, including non-Hodgkin's lymphoma (70). It is used as a possible marker for residual disease in acute myeloid leukemia (AML) after chemotherapy (71). To the best of our knowledge, the present study aimed for the first time to discover the expression levels of WT-1 in all studied CTCL cell lines. WT-1 was overexpressed in HuT-78 cells, followed by an intermediate expression in MJ cells and a low one in HH cells (Fig. 6). Notably, the present finding, compared with the cytotoxic experiments, revealed that WT-1 may serve an important role in cell resistance against cytotoxic agents, such as curcumin. This result shifted the focus of the present study to the more resistant cell lines, mainly HuT-78 and to some extent MJ cells.

Further analysis of the signal transduction changes triggered by CRM (P123/F127) in HuT-78 cells. Subsequent experiments aimed to further investigate the signal transduction changes induced by the novel nanosized curcumin in the most resistant cell line, HuT-78, which in the current study represented patients with SS, the leukemic form of CTCL. CRM (P123/F127) upregulated the pro-apoptotic factors Bad, Bax and p21 Waf1/Cip1, while it had no effect on the anti-apoptotic protein BCL-2. CRM (P123/F127) downregulated the transcription factor WT-1, p-STAT3, p-STAT5, p-PLC $\gamma 1$ and p-GSK3- $\beta$. Lastly, it had no effect on selected proteins belonging to the mTOR signaling pathway, namely mTOR, p-mTOR, Raptor and Rictor (Fig. 7).

\section{Discussion}

In an era where targeted therapies (together with immunotherapy) are on the rise for cancer treatment (72-76), the identification of natural substances with antineoplastic properties and minimal toxicity, such as curcumin, may improve existing therapeutic approaches. In the present study, the

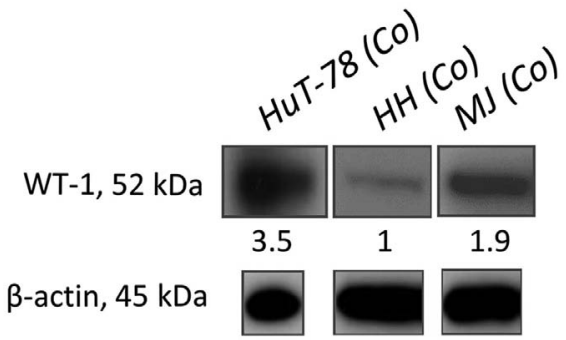

Figure 6. Comparison of WT-1 expression between the Co groups of the three studied cell lines (the blots were performed on different membranes, one for each cell line) after $24 \mathrm{~h}$ of incubation. WT-1 levels were normalized to the weakest expressed signal (HH cell line). Co., control; WT-1, Wilms' tumor 1.

cytotoxic efficacy and internalization rate of curcumin was enhanced by its incorporation into a novel nanosized system consisting of an aqueous solution of Pluronic ${ }^{\circledR} \mathrm{P}-123$ and Pluronic ${ }^{\circledR} \mathrm{F}-127(1: 1 \mathrm{v} / \mathrm{v})$. This enhancement was reflected at the molecular level by the inhibition of $\mathrm{NF}-\kappa \mathrm{B}$ p 65 , which was induced to a greater extent by the curcumin-loaded micelles than by the standard ethanol solution of curcumin, measured using a specific ELISA. The inhibition of NF- $\kappa \mathrm{B}$ p65 is associated with a reduction of inflammatory changes and tumor cell drug resistance (66,77-80). The ELISA method represents a faster and easier alternative to the electrophoresis mobility shift assay, giving the opportunity to quantify the activation of the transcription factor NF- $\kappa$ B. Dephosphorylation of $\mathrm{p} 65$ $\mathrm{NF}-\kappa \mathrm{B}$ by CRM (EtOH) as measured via western blotting was in accordance with the result obtained using the specific ELISA NFאB p65 (Total/Phospho) kit, as both tests demonstrated downregulation of NF- $\kappa \mathrm{B}$.

To the best of our knowledge western blotting revealed for the first time that another transcription factor, WT-1, was expressed in CTCL cells and may be involved in the molecular pathogenesis of CTCL. Notably, in the present study WT-1 expression was found to be directly associated with cytotoxic sensitivity to curcumin, with the HuT-78 cell line which expressed high levels of WT-1 being the most resistant, followed 

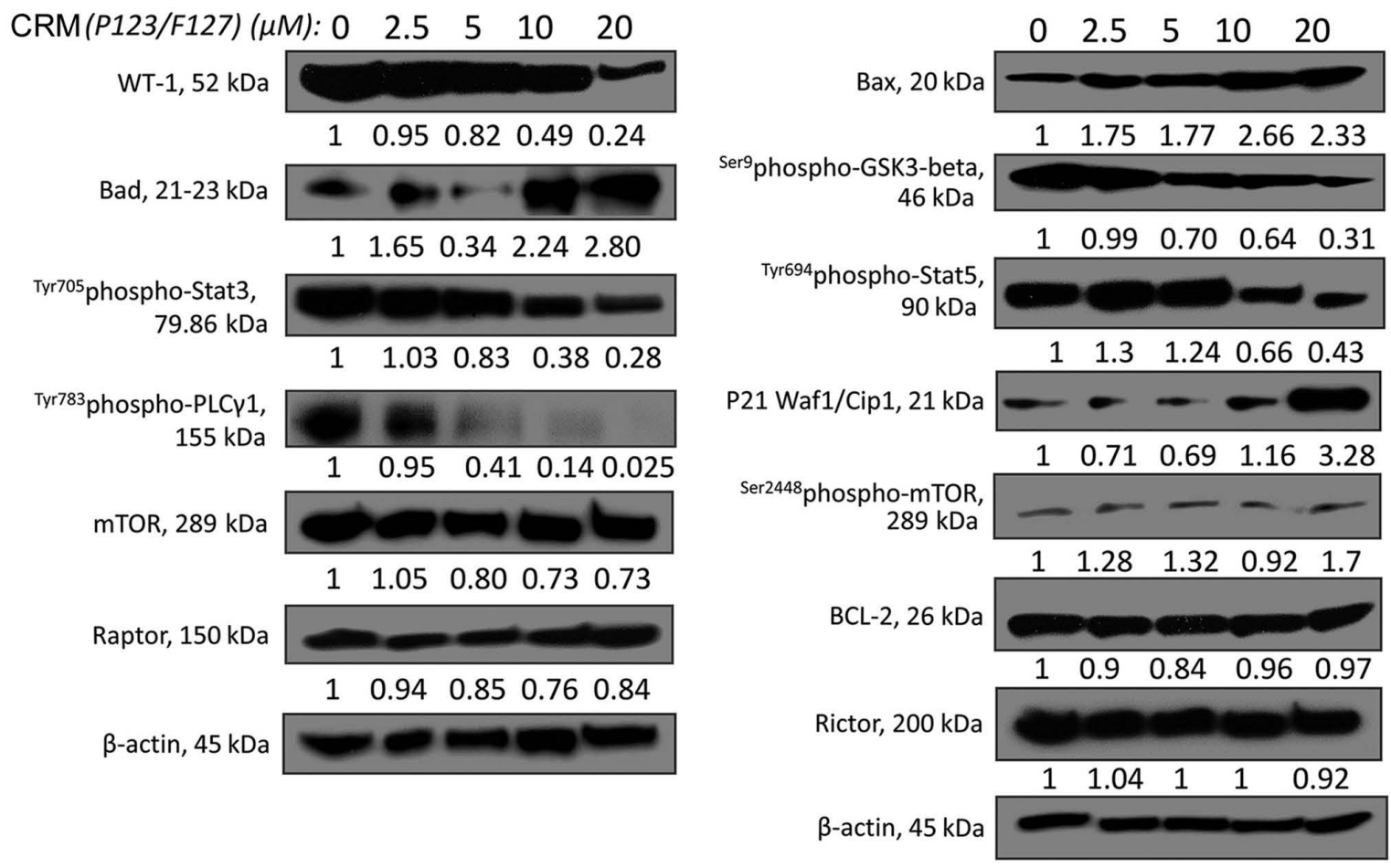

Figure 7. Molecular changes induced by CRM (P123/F127) on the most resistant cell line, HuT-78, after $24 \mathrm{~h}$ of treatment. The numbers under the protein blots represent the signal intensity normalized to the corresponding untreated control via densitometric analysis. CRM (P123/F127), curcumin-loaded micelles consisting of Pluronic ${ }^{\circledR}$ P-123 and Pluronic ${ }^{\circledR}$ F-127 (1:1 v/v); PLC, phospholipase C; GSK, glycogen synthase kinase; WT-1, Wilms' tumor 1.

by MJ and lastly HH cells. CRM (P123/F127) suppressed the relatively high expression levels of WT-1 in HuT-78 cells, originating from the leukemic variant of the disease, known as SS. The present result may prove to be of great importance if a link between the upregulation of this transcription factor and a poor prognostic outcome is identified, similar to that between WT-1 and AML (71,81-83). Furthermore, WT-1 downregulation may reflect the curcumin-induced lymphoma cell differentiation.

The evidence of the association between ALK, a receptor tyrosine kinase, and various types of human cancer is well established, with ALK upregulation being present in a variety of human tumors and cell lines such as those of non-small-cell lung cancer (NSCLC), melanoma, glioblastoma and lymphoma (84). ALK-positivity in CTCL is rare and associated with an aggressive course (85). The activation of the ALK protein is due to a chromosomal translocation, mainly $\mathrm{t}(2 ; 5)(\mathrm{p} 23 ; \mathrm{q} 35)$, leading to a fusion protein with constitutive kinase activity, which is associated with an aggressive course of CTCL (85). In the present study, curcumin downregulated ALK, as well as the phosphorylated form of one of the downstream effectors of ALK, PLC $\gamma$, which may serve an important role in the progression of the disease. Bona fide gain of function mutations of PLC $\gamma 1$, the PLC $\gamma$ form predominantly expressed by $\mathrm{T}$ cells (86), lead to the constitutive activation of proximal and distal PLC $\gamma 1$ signaling cascades, including the activation of $\mathrm{NF}-\kappa \mathrm{B}$, with the inhibition of this pathway resulting in decreased CTCL cell proliferation and viability (87-89).

In accordance with the aforementioned findings, upregulation of the pro-apoptotic proteins Bad, Bax and p21
Waf1/Cip1 by curcumin was also observed in the present study. Furthermore, curcumin inhibited important proteins involved in the JAK-STAT signaling pathway, which have an essential role in the pathogenesis of CTCL $(89,90)$, and the phosphorylated form of GSK-3 $\beta$. The association between the inhibition of JAK and GSK-3 $\beta$ to promote cell death in CTCL cells has been described in previous studies. Pérez et al (91) demonstrated that ruxolitinib (a specific JAK inhibitor) exerts a dose-dependent cytotoxicity on CTCL cells, while Rovedo et al (92) revealed that the inhibition of GSK-3 $\beta$ increases the cytotoxic activity of enzastaurin (a protein kinase C $\beta$ inhibitor) against CTCL cells. This inhibition probably affects cell proliferation and survival via the already

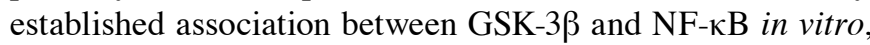
as well as in vivo (92).

Considering the emerging primary or secondary mechanisms of resistance developed by neoplasms to mAbs and small molecule inhibitors, such as C481S point mutation, PLC $\gamma 2$ gain-of-function mutation, constitutive PI3K/Akt and $\mathrm{NF}-\kappa \mathrm{B}$ signaling pathways activation (93-96), as well as novel molecular data (demonstrated in the present study) clarifying the pleiotropic mode of action of curcumin, this natural substance may be used in combination with targeted therapies. More specifically, curcumin may be used to augment the therapeutic efficacy of currently used targeted agents, such as crizotinib (ALK inhibitor), ruxolitinib (JAK inhibitor), denosumab and bortezomib (NF- $\kappa \mathrm{B}$ inhibitors), especially in patients with SS, the leukemic form of the disease that frequently requires aggressive systemic chemotherapy. In addition, the use of a combination of curcumin and ruxolitinib for skin application has a logical foundation, firstly because 
ruxolitinib is already used topically for the treatment of skin diseases, such as vitiligo and atopic dermatitis (97-100), and secondly due to the fact that ruxolitinib inhibits the growth of CTCL cells in vitro (91). Similar combination treatment schedules may become even more feasible by incorporating curcumin into nanoparticles, such as the novel nanosized aqueous solution of Pluronic ${ }^{\circledR} \mathrm{P}-123$ and Pluronic ${ }^{\circledR} \mathrm{F}-127$ identified in the present study. The latter may serve as effective curcumin-delivery system and improve its pharmacokinetic and cytotoxic properties, making the substance more potent and suitable for systemic and topical application on patch lesions or skin tumors associated with CTCL.

In conclusion, experimental findings of the present study indicated that curcumin may be used as a prospective single-agent compound or as a partner in combination schedules for CTCL, especially after inclusion in nanosized drug delivery systems. Further studies on curcumin combinations with other complementary acting antineoplastic agents in CTCL models are warranted.

\section{Acknowledgements}

The authors of the present study would like to thank Professor Chem. Eng. Alexander Dimitrov Kroumov, Department of Biotechnology, The Stephan Angeloff Institute of Microbiology, Bulgarian Academy of Sciences (Sofia, Bulgaria), for reviewing the statistical analyses of all experiments. A number of the cytotoxic experiments were performed using laboratory equipment donated by the Alexander von Humboldt Foundation (Grant 'Equipment Subsidies', Certificate of Donation from Department 3.4/V-8151/14038) to Maya M. Zaharieva, Ph.D., for establishing a 'Laboratory for in vitro cytotoxicity and signal transduction' at the Department of Infectious Microbiology, The Stephan Angeloff Institute of Microbiology, Bulgarian Academy of Sciences (Sofia, Bulgaria).

\section{Funding}

The present study was supported by a research grant for 'Doctoral candidates and young academics and scientists' by the German Academic Exchange Service (DAAD), the Erasmus+ program and the Bulgarian National Science Foundation [grant no. DN 03/3 (2016-2020)].

\section{Availability of data and materials}

The datasets used and/or analyzed during the present study are available from the corresponding author upon reasonable request.

\section{Authors' contributions}

AGXT conceived, designed and performed the experiments. MMZ co-designed and helped with the performance of the cytotoxic experiments. MHM helped with the performance of the western blot experiments. IPET designed and performed the spectrophotometric experiments for the detection of the overlapping absorbances of curcumin and phenol red, as well as for the detection of the amount of curcumin in the cell culture media. KY designed and loaded the copolymeric micelles with curcumin. MRB and SMK helped with the conception of the study, its supervision, and reviewed the first version of the manuscript before its submission. All authors have read and approved the final version of the manuscript.

\section{Ethics approval and consent to participate}

Not applicable.

\section{Patient consent for publication}

Not applicable.

\section{Competing interests}

The authors declare that they have no competing interests.

\section{References}

1. Hwang ST, Janik JE, Jaffe ES and Wilson WH: Mycosis fungoides and Sézary syndrome. Lancet 371: 945-957, 2008.

2. Willemze R, Kerl H, Sterry W, Berti E, Cerroni L, Chimenti S, Diaz-Peréz JL, Geerts ML, Goos M, Knobler R, et al: EORTC classification for primary cutaneous lymphomas: As proposal from the cutaneous lymphoma study group of the European organization for research and treatment of cancer. Blood 90: 354-371, 1997.

3. Willemze R, Jaffe ES, Burg G, Cerroni L, Berti E, Swerdlow SH, Ralfkiaer E, Chimenti S, Diaz-Perez JL, Duncan LM, et al: WHO-EORTC classification for cutaneous lymphomas. Blood 105: 3768-3785, 2005.

4. Burg G, Kempf W, Cozzio A, Feit J, Willemze R, S Jaffe E, Dummer R, Berti E, Cerroni L, Chimenti S, et al: WHO/EORTC classification of cutaneous lymphomas 2005: Histological and molecular aspects. J Cutan Pathol 32: 647-674, 2005.

5. Girardi M, Heald PW and Wilson LD: The pathogenesis of mycosis fungoides. N Engl J Med 350: 1978-1988, 2004.

6. Manso R, Martínez-Magunacelaya N, Eraña-Tomás I, Monsalvez V, Rodríguez-Peralto JL, Ortiz-Romero PL, Santonja C, Cristóbal I, Piris MA and Rodríguez-Pinilla SM: Mycosis fungoides progression could be regulated by microRNAs. PLoS One 13: e0198477, 2018.

7. Criscione VD and Weinstock MA: Incidence of cutaneous T-cell lymphoma in the United States, 1973-2002. Arch Dermatol 143: 854-859: 2007.

8. Hutchinson CB, Stoecker M, Wang FF, Papalas J, Sebastian S, Burchette J, Datto M and Wang E: Molecular detection of circulating Sezary cells in patients with mycosis fungoides: Could it predict future development of secondary Sezary syndrome? A single-institution experience. Leuk Lymphoma 53: 868-877, 2012.

9. Wu XS, Lonsdorf AS and Hwang ST: Cutaneous T-cell lymphoma: Roles for chemokines and chemokine receptors. J Invest Dermatol 129: 1115-1119, 2009.

10. Yamashita T, Abbade LP, Marques ME and Marques SA: Mycosis fungoides and Sezary syndrome: Clinical, histopathological and immunohistochemical review and update. An Bras Dermatol 87: 817-830, 2012.

11. Yumeen S and Girardi M: Insights into the molecular and cellular underpinnings of cutaneous $\mathrm{T}$ cell lymphoma. Yale $\mathrm{J}$ Biol Med 93: 111-121, 2020.

12. Prince HM, Whittaker S and Hoppe RT: How I treat mycosis fungoides and Sézary syndrome. Blood 114: 4337-4353, 2009.

13. Wollina U: Cutaneous T cell lymphoma: Update on treatment. Int J Dermatol 51: 1019-1036, 2012.

14. Esche BA and Fitzpatrick PJ: Cutaneous malignant lymphoma. Int J Radiat Oncol Biol Phys 12: 2111-2115, 1986.

15. Zucca E and Cavalli F: Extranodal lymphomas. Ann Oncol 11 (Suppl 3): S219-S222, 2000

16. Sokołowska-Wojdyło M, Olek-Hrab K and RuckemannDziurdzińska K: Primary cutaneous lymphomas: Diagnosis and treatment. Postepy Dermatol Alergol 32: 368-383, 2015. 
17. Richter T, Nestler-Parr S, Babela R, Khan ZM, Tesoro T, Molsen E and Hughes DA; International Society for Pharmacoeconomics and Outcomes Research Rare Disease Special Interest Group: Rare disease terminology and definitions-A systematic globa review: Report of the ISPOR rare disease special interest group. Value Health 18: 906-914, 2015.

18. Orphanet: Orphanet: An online rare disease and orphan drug data base. (C) INSERM 1999. http://www.orpha.net, 2019.

19. Okoye AA and Picker LJ: CD4(+) T-cell depletion in HIV infection: Mechanisms of immunological failure. Immunol Rev 254 54-64, 2013

20. Vidya Vijayan KK, Karthigeyan KP, Tripathi SP and Hanna LE: Pathophysiology of CD4 ${ }^{+}$T-Cell Depletion in HIV-1 and HIV-2 Infections. Front Immunol 8: 580, 2017.

21. Krejsgaard T, Odum N, Geisler C, Wasik MA and Woetmann A: Regulatory $\mathrm{T}$ cells and immunodeficiency in mycosis fungoides and Sézary syndrome. Leukemia 26: 424-432, 2012.

22. Heald P, Yan SL and Edelson R: Profound deficiency in normal circulating $\mathrm{T}$ cells in erythrodermic cutaneous T-cell lymphoma. Arch Dermatol 130: 198-203, 1994.

23. Coondoo A, Phiske M, Verma S and Lahiri K: Side-effects of topical steroids: A long overdue revisit. Indian Dermato Online J 5: 416-425, 2014.

24. Farber EM, Abel EA and Cox AJ: Long-term risks of psoralen and UV-A therapy for psoriasis. Arch Dermatol 119: 426-431, 1983

25. Farol LT and Hymes KB: Bexarotene: A clinical review. Expert Rev Anticancer Ther 4: 180-188, 2004.

26. Nurgali K, Jagoe RT and Abalo R: Editorial: Adverse effects of cancer chemotherapy: Anything new to improve tolerance and reduce sequelae? Front Pharmacol 9: 245, 2018.

27. Sleijfer S, Bannink M, Van Gool AR, Kruit WH and Stoter G: Side effects of interferon-alpha therapy. Pharm World Sci 27: 423-431, 2005

28. Subramanian S, Bates SE, Wright JJ, Espinoza-Delgado I and Piekarz RL: Clinical toxicities of histone deacetylase inhibitors. Pharmaceuticals (Basel) 3: 2751-2767, 2010.

29. Vidula N, Villa M, Helenowski IB, Jovanovic BD, Meagher R, Mehta J, Singhal S, Winter JN, Frankfurt O, Altman JK, et al: Adverse events during hematopoietic stem cell infusion: Analysis of the infusion product. Clin Lymphoma Myeloma Leuk 15 e157-e162, 2015.

30. Tsambiras PE, Patel S, Greene JN, Sandin RL and Vincent AL: Infectious complications of cutaneous T-cell lymphoma. Cancer Control 8: 185-188, 2001.

31. Sharma RA, Gescher AJ and Steward WP: Curcumin: The story so far. Eur J Cancer 41: 1955-1968, 2005.

32. Hsu CH and Cheng AL: Clinical studies with curcumin. Adv Exp Med Biol 595: 471-480, 2007.

33. Zhang C, Li B, Zhang X, Hazarika P, Aggarwal BB and Duvic M: Curcumin selectively induces apoptosis in cutaneous T-cell lymphoma cell lines and patients' PBMCs: Potential role for STAT-3 and NF-kappaB signaling. J Invest Dermatol 130: 2110-2119, 2010.

34. Khan MA, Gahlot S and Majumdar S: Oxidative stress induced by curcumin promotes the death of cutaneous T-cell lymphoma (HuT-78) by disrupting the function of several molecular targets. Mol Cancer Ther 11: 1873-1883, 2012.

35. Yosifov DY, Kaloyanov KA, Guenova ML, Prisadashka K, Balabanova MB, Berger MR and Konstantinov SM Alkylphosphocholines and curcumin induce programmed cell deathin cutaneous T-cell lymphoma cell lines. Leuk Res 38 : 49-56, 2014.

36. Devaraj S, Jagannathan N and Neelakantan P: Antibiofilm efficacy of photoactivated curcumin, triple and double antibiotic paste, $2 \%$ chlorhexidine and calcium hydroxide against Enterococcus fecalis in vitro. Sci Rep 6: 24797, 2016.

37. Trochopoulos A, Ivanov E, Yakub G, Rashkov I, Manolova N Momekova D, Zaharieva MM, Najdenski H, Berger MR and Konstantinov S: Antineoplastic potential of curcumin loaded polymeric formulations against human malignant cells. Humboldt Union in Bulgaria, Sofia, Bulgaria, pp 44-572018.

38. Zaharieva MM, Kroumov AD, Dimitrova L, Tsvetkova I, Trochopoulos A, Konstantinov SM, Berger MR, Momchilova M, Yoncheva K and Najdenski HM: Micellar curcumin improves the antibacterial activity of the alkylphosphocholines erufosine and miltefosine against pathogenic Staphyloccocus aureus. Biotechnol Biotechnological Equip 33: 38-53, 2019.

39. Axelrod PI, Lorber B and Vonderheid EC: Infections complicating mycosis fungoide and sézary syndrome. JAMA 267: $1354-1358,1992$
40. Bonin S, Tothova SM, Barbazza R, Brunetti D, Stanta G and Trevisan G: Evidence of multiple infectious agents in mycosis fungoides lesions. Exp Mol Pathol 89: 46-50, 2010.

41. Willerslev-Olsen A, Krejsgaard T, Lindahl LM, Bonefeld CM, Wasik MA, Koralov SB, Geisler C, Kilian M, Iversen L, Woetmann A and Odum N: Bacterial toxins fuel disease progression in cutaneous T-cell lymphoma. Toxins (Basel) 5: 1402-1421, 2013.

42. Kunwar A, Barik A, Pandey R and Priyadarsini KI: Transport of liposomal and albumin loaded curcumin to living cells: An absorption and fluorescence spectroscopic study. Biochim Biophys Acta 1760: 1513-1520, 2006.

43. Anand P, Kunnumakkara AB, Newman RA and Aggarwal BB Bioavailability of curcumin: Problems and promises. Mol Pharm 4: 807-818, 2007.

44. Aggarwal BB, Sundaram C, Malani N and Ichikawa H: Curcumin: The Indian solid gold. Adv Exp Med Biol 595: 1-75: 2007.

45. Goel A, Kunnumakkara AB and Aggarwal BB: Curcumin as 'Curecumin': From kitchen to clinic. Biochem Pharmacol 75: 787-809, 2008

46. Mohanty $\mathrm{C}$ and Sanjeeb $\mathrm{K}$ : The in vitro stability and in vivo pharmacokinetics of curcumin prepared as an aqueous nanoparticulate formulation. Biomaterials 31 6597-6611, 2010.

47. Song Z, Feng R, Sun M, Guo C, Gao Y, Li L and Zhai G: Curcumin-loaded PLGA-PEG-PLGA triblock copolymeric micelles: Preparation, pharmacokinetics and distribution in vivo. J Colloid Interface Sci 354: 116-123, 2011

48. Li R, Qiao X, Li Q, He R, Ye M, Xiang C, Lin X and Guo D: Metabolic and pharmacokinetic studies of curcumin, demethoxycurcumin and bisdemethoxycurcumin in mice tumor after intragastric administration of nanoparticle formulations by liquid chromatography coupled with tandem mass spectrometry. J Chromatogr B Analyt Technol Biomed Life Sci 879: 2751-2758, 2011.

49. Yallapu MM, Jaggi M and Chauhan SC: Curcumin nanoformulations: A future nanomedicine for cancer. Drug Discov Today 17 71-80, 2012

50. Jelezova I,Drakalska E, Momekova D, Shalimova N, Momekov G, Konstantinov S, Rangelov S and Pispas S: Curcumin loaded $\mathrm{pH}$-sensitive hybrid lipid/block copolymer nanosized drug delivery systems. Eur J Pharm Sci 78: 67-78, 2015.

51. Mehanny M, Hathout RM, Geneidi AS and Mansour S: Exploring the use of nanocarrier systems to deliver the magical molecule; Curcumin and its derivatives. J Control Release 225: 1-30, 2016.

52. Klement JF, Rice NR, Car BD, Abbondanzo SJ, Powers GD Bhatt PH, Chen CH, Rosen CA and Stewart CL: IkappaBalpha deficiency results in a sustained NF-kappaB response and severe widespread dermatitis in mice. Mol Cell Biol 16: 2341-2349, 1996.

53. Mosmann T: Rapid colorimetric assay for cellular growth and survival: Application to proliferation and cytotoxicity assays. J Immunol Methods 65: 55-63, 1983.

54. Konstantinov SM, Eibl $\mathrm{H}$ and Berger MR: BCR-ABL influences the antileukaemic efficacy of alkylphosphocholines. Br J Haematol 107: 365-374, 1999.

55. Van Meerloo J, Kaspers GJ and Cloos J: Cell sensitivity assays: The MTT assay. Methods Mol Biol 731: 237-245, 2011.

56. Bradford MM: A rapid and sensitive method for the quantitation of microgram quantities of protein utilizing the principle of protein-dye binding. Anal Biochem 72: 248-254, 1976

57. Schneider CA, Rasband WS and Eliceiri KW: NIH image to imageJ: 25 years of image analysis. Nat Methods 9: 671-675, 2012.

58. Abramoff MD, Magalhães PJ and Ram SJ: Image processing with ImageJ. Biophot Int 11: 36-42, 2004.

59. Swinehart DF: The Beer-Lambert Law. J Chem Educ 39: 333 1962.

60. Hayden MS, West AP and Ghosh S: NF-kappaB and the immune response. Oncogene 25: 6758-6780, 2006.

61. Liu T, Zhang L, Joo D and Sun SC: NF- $\kappa B$ signaling in inflammation. Signal Transduct Target Ther 2: 17023, 2017.

62. Xia Y, Shen S and Verma IM: NF- $\kappa$ B, an active player in human cancers. Cancer Immunol Res 2: 823-830, 2014.

63. Baldwin AS: Regulation of cell death and autophagy by IKK and $\mathrm{NF}-\kappa \mathrm{B}$ : Critical mechanisms in immune function and cancer. Immunol Rev 246: 327-345, 2012.

64. Juvekar A, Manna S, Ramaswami S, Chang TP, Vu HY, Ghosh CC, Celiker MY and Vancurova I: Bortezomib induces nuclear translocation of I $\mathrm{B} \alpha$ resulting in gene-specific suppression of NF- $\kappa \mathrm{B}$-dependent transcription and induction of apoptosis in CTCL. Mol Cancer Res 9: 183-194, 2011. 
65. Kiessling MK, Klemke CD, Kaminski MM, Galani IE, Krammer PH and Gulow K: Inhibition of constitutively activated nuclear factor-kappaB induces reactive oxygen species- and iron-dependent cell death in cutaneous T-cell lymphoma. Cancer Res 69: 2365-2374, 2009.

66. Sors A, Jean-Louis F, Pellet C, Laroche L, Dubertret L, Courtois G, Bachelez H and Michel L: Down-regulating constitutive activation of the NF-kappaB canonical pathway overcomes the resistance of cutaneous T-cell lymphoma to apoptosis. Blood 107: 2354-2363, 2006.

67. Call KM, Glaser T, Ito CY, Buckler AJ, Pelletier J, Haber DA Rose EA, Kral A, Yeger H, Lewis WH, et al: Isolation and characterization of a zinc finger polypeptide gene at the human chromosome 11 Wilms' tumor locus. Cell 60: 509-520, 1990.

68. Gessler M, Poustka A, Cavenee W, Neve RL, Orkin SH and Bruns GA: Homozygous deletion in Wilms tumours of a zinc-finger gene identified by chromosome jumping. Nature 343: 774-778, 1990

69. Huang A, Campbell CE, Bonetta L, McAndrews-Hill MS Chilton-MacNeill S, Coppes MJ, Law DJ, Feinberg AP, Yeger H and Williams BR: Tissue, developmental, and tumor-specific expression of divergent transcripts in Wilms tumor. Science 250: 991-994, 1990

70. Ujj Z, Buglyo G, Udvardy M, Vargha G, Biro S and Rejto L: WT1 overexpression affecting clinical outcome in non-hodgkin lymphomas and adult acute lymphoblastic leukemia. Pathol Oncol Res 20: 565-570, 2014.

71. Casalegno-Garduno R, Schmitt A, Spitschak A, Greiner J, Wang L, Hilgendorf I, Hirt C, Ho AD, Freund M and Schmitt M: Immune responses to WT1 in patients with AML or MDS after chemotherapy and allogeneic stem cell transplantation. Int $\mathrm{J}$ Cancer 138: 1792-1801, 2016

72. Baudino TA: Targeted cancer therapy: The next generation of cancer treatment. Curr Drug Discov Technol 12: 3-20, 2015.

73. Kumar M, Nagpal R, Hemalatha R, Verma V, Kumar A, Singh S, Marotta F, Jain S and Yadav H: Targeted cancer therapies: The future of cancer treatment. Acta Biomed 83: 220-233, 2012

74. Wraith DC: The future of immunotherapy: A 20-year perspective. Front Immunol 8: 1668, 2017

75. Yu Y and Cui J: Present and future of cancer immunotherapy: A tumor microenvironmental perspective. Oncol Lett 16 : 4105-4113, 2018

76. Zhang $\mathrm{H}$ and Chen J: Current status and future directions of cancer immunotherapy. J Cancer 9: 1773-1781, 2018.

77. DiDonato JA, Mercurio F and Karin M: NF- $\mathrm{BB}$ and the link between inflammation and cancer. Immunol Rev 246: 379-400, 2012.

78. Godwin P, Baird AM, Heavey S, Barr MP, O'Byrne KJ and Gately K: Targeting nuclear factor-kappa B to overcome resistance to chemotherapy. Front Oncol 3: 120, 2013.

79. Moore MM, Chua W, Charles KA and Clarke SJ: Inflammation and cancer: Causes and consequences. Clin Pharmacol Ther 87: 504-508, 2010

80. Hoesel B and Schmid JA: The complexity of NF- $\mathrm{BB}$ signaling in inflammation and cancer. Mol Cancer 12: 86, 2013.

81. Candoni A, Toffoletti E, Gallina R, Simeone E, Chiozzotto M, Volpetti S and Fanin R: Monitoring of minimal residual disease by quantitative WT1 gene expression following reduced intensity conditioning allogeneic stem cell transplantation in acute myeloid leukemia. Clin Transplant 25: 308-316, 2011.

82. Nowakowska-Kopera A, Sacha T, Florek I, Zawada M, Czekalska S and Skotnicki AB: Wilms' tumor gene 1 expression analysis by real-time quantitative polymerase chain reaction for monitoring of minimal residual disease in acute leukemia. Leuk Lymphoma 50: 1326-1332, 2009.

83. Spassov BV, Stoimenov AS, Balatzenko GN, Genova ML, Peichev DB and Konstantinov SM: Wilms' tumor protein and FLT3-internal tandem duplication expression in patients with de novo acute myeloid leukemia. Hematology 16: 37-42, 2011.

84. Hallberg B and Palmer RH: Mechanistic insight into ALK receptor tyrosine kinase in human cancer biology. Nat Rev Cancer 13: 685-700, 2013.
85. Wehkamp U, Oschlies I, Nagel I, Brasch J, Kneba M, Günther A, Klapper W and Weichenthal M: ALK-positive primary cutaneous T-cell-lymphoma (CTCL) with unusual clinical presentation and aggressive course. J Cutan Pathol 42: $870-877,2015$

86. Stoica GE, Kuo A, Aigner A, Sunitha I, Souttou B, Malerczyk C, Caughey DJ, Wen D, Karavanov A, Riegel AT and Wellstein A Identification of anaplastic lymphoma kinase as a receptor for the growth factor pleiotrophin. J Biol Chem 276: 16772-16779, 2001.

87. Patel VM, Flanagan CE, Martins M, Jones CL, Butler RM, Woollard WJ, Bakr FS, Yoxall A, Begum N, Katan M, et al: Frequent and persistent PLCG1 mutations in sezary cells directly enhance PLC $\mathrm{Y}^{1}$ activity and stimulate NFKB, AP-1, and NFAT signaling. J Invest Dermatol 140: 380-389.e4, 2020 .

88. Smith-Garvin JE, Koretzky GA and Jordan MS: T cell activation. Annu Rev Immunol 27: 591-619, 2009.

89. Vaque JP, Gomez-Lopez G, Monsalvez V, Varela I, Martínez N, Pérez C, Domínguez O, Graña O, Rodríguez-Peralto JL, Rodríguez-Pinilla SM, et al: PLCG1 mutations in cutaneous T-cell lymphomas. Blood 123: 2034-2043, 2014

90. Kiessling MK, Oberholzer PA, Mondal C, Karpova MB Zipser MC, Lin WM, Girardi M, Macconaill LE, Kehoe SM, Hatton C, et al: High-throughput mutation profiling of CTCL samples reveals KRAS and NRAS mutations sensitizing tumors toward inhibition of the RAS/RAF/MEK signaling cascade. Blood 117: 2433-2440, 2011.

91. Pérez C, González-Rincón J, Onaindia A, Almaráz C, García-Díaz N, Pisonero H, Curiel-Olmo S, Gómez S, Cereceda L, Madureira R, et al: Mutated JAK kinases and deregulated STAT activity are potential therapeutic targets in cutaneous T-cell lymphoma. Haematologica 100: e450-e453, 2015.

92. Rovedo MA, Krett NL and Rosen ST: Inhibition of glycogen synthase kinase-3 increases the cytotoxicity of enzastaurin. J Invest Dermatol 131: 1442-1449, 2011

93. Balaji S, Ahmed M, Lorence E, Yan F, Nomie K and Wang M: $\mathrm{NF}-\mathrm{\kappa B}$ signaling and its relevance to the treatment of mantle cell lymphoma. J Hematol Oncol 11: 83, 2018.

94. Merolle MI, Ahmed M, Nomie K and Wang ML: The B cell receptor signaling pathway in mantle cell lymphoma. Oncotarget 9: 25332-25341, 2018.

95. Rosenthal A: Small molecule inhibitors in chronic lymphocytic lymphoma and B cell non-hodgkin lymphoma. Curr Hematol Malig Rep 12: 207-216, 2017.

96. Valla K, Flowers CR and Koff JL: Targeting the B cell receptor pathway in non-Hodgkin lymphoma. Expert Opin Investig Drugs 27: 513-522, 2018.

97. Kim BS, Howell MD, Sun K, Papp K, Nasir A and Kuligowski ME; INCB 18424-206 Study Investigators: Treatment of atopic dermatitis with ruxolitinib cream (JAK1/JAK2 inhibitor) or triamcinolone cream. J Allergy Clin Immunol 145: 572-582, 2020.

98. Owens S and Howell MD: Ruxolitinib cream suppresses Th2 inflammation in adult patients with atopic dermatitis. J Allergy Clin Immunol 143: AB128, 2019.

99. Rosmarin D, Pandya AG, Lebwohl M, Grimes P, Hamzavi I, Gottlieb AB, Butler K, Kuo F, Sun K, Ji T, et al: Ruxolitinib cream for treatment of vitiligo: A randomised, controlled, phase 2 trial. Lancet 396: 110-120, 2020.

100. Rothstein B, Joshipura D, Saraiya A, Abdat R, Ashkar H, Turkowski Y, Sheth V, Huang V, Au SC, Kachuk C, et al: Treatment of vitiligo with the topical Janus kinase inhibitor ruxolitinib. J Am Acad Dermatol 76: 1054-1060.e1, 2017.

This work is licensed under a Creative Commons Attribution-NonCommercial-NoDerivatives 4.0 International (CC BY-NC-ND 4.0) License. 